\title{
Literature, Truth and History in GenJI Monogatarl by MURASAKI SHIKIBU
}

FLORINA ILIS

\begin{abstract}
In the present study, I will analyse the understanding of the relation between literature/fiction and history in the novel Genji monogatari 源氏物語 by Murasaki Shikibu. The research conducted on the three types of discourse - literary, historical and religious -, intriguingly conveyed by the author of the novel Genji monogatari, offers the text, besideS its aesthetic, literary value, a poetic valence. Avoiding theorisation, Murasaki Shikibu manages to express the specificity of each type of discourse by INDICATING the key in which each must be understood. Beginning with a focus on the specificity of these discourses, from the viewpoint of discourse poetics, I analysed Murasaki Shikibu's means of defining fiction, as well as her contribution to the invention of the novel as monogatari, namely a new, imaginary story, in contrast with the older, mukashi monogatari type stories, in which temporality is suspended.
\end{abstract}

Keywords Japanese literature, Genji monogarari, Murasaki Shikibu, monogatari (as a literary genre).

The subject of the relation between history and literature is undoubtedly one of the oldest themes of poetics but, in spite of its longevity, it is also a continuously current theme, since each generation sought to offer their own views and a new interpretation of the relation between history as a narration and literature seen as an imaginary history. A re-evaluation of this relation is particularly necessary in a period in which, through the influence of postmodern poetics, the discourse styles intertwine, migrating from one field to the other and contaminating each other, thus creating new genres, located somewhere between the historical discourse and the literary discourse.

* Babeș-Bolyai University, Cluj-Napoca. ilisflorina@gmail.com.

DOI: 10.26424/philobib.2021.26.2.03 
The first attempts to differentiate the writing genres were made by Plato who, in Book III of The Republic (The Republic, III, 394c, cited edition), analyses the diegesis, the story, and, depending on the presence or absence of direct discourse, he discerned three means of expression: the simple means, when the story is in an indirect discourse (unattested style), the imitative means or mimesis, ${ }^{1}$ as is the case of the tragedies in which everything is in direct discourse, and the mixed means, as is the case of the epics (The Iliad), in which the latter two merge. Thus, according to Plato, mimesis offers the illusion that the story is assumed by someone other than the author.

In Poetics, Aristotle borrows the term mimesis but modifies its use, showing that within mimesis, the tragedy and the epic are opposed in terms of direct (a representation of history) versus indirect (a recount of history). The mimesis, in Aristotle's view, covers not only tragedy, but also the story or the narration, because, both in the epic and in the tragedy, the mimesis is the mythos story, as a mimesis of the plot and thus of the narration, first and foremost, not of the description. Thus, Aristotle, in an attempt to explain not the relation between literature and reality, but the creation of a verisimilar poetic fiction, did not focus on the imitated or represented object, but on the technique for the representation and structure of the mythos ${ }^{2}$ (Poetics, VI, 5, 1450a, cited edition). For Aristotle, the mimesis became the plausible representation of human actions and the narrative organisation of facts within the story. For Aristotle, the poet may choose from reality even what is impossible, provided it is verisimilar and necessary, rather than representing what is possible in an unconvincing way.

In order to distinguish the literary discourse from the historical discourse, Aristotle states that literature is more philosophical than history because the historian depicts facts that had truly taken place, while the poet depicts facts that could have taken place, i.e., the general and the probable. Beginning from Aristotle's statement, the first clear distinction was made between literature and history. Thus, the epic poet was able to choose the facts he would narrate and to select them based not on their real nature, but on the intention of the epic - even the ones that are untrue but convincing. Therefore, literature deals with the imaginary truth, while history deals with the historical truth.

A similar situation is also present in the Japanese novel Genji monogatari 源氏物語 written at the beginning of the $11^{\text {th }}$ century by Murasaki Shikibu (973? 1014?), a court lady of the empress Fujiwara no Shōshi (藤原彰子, 988 -1074) from the Heian Court. The novel Genji monogatari contains 54 chapters, and the plot

\footnotetext{
1 Plato, Opere [Complete Works], vol. V, transl. and ed. by Andrei Cornea (Bucharest: Editura Științifică și Enciclopedică, 1986), 167.

2 Aristotle, Poetica [Poetics], transl. and ed. by D. M. Pippidi (Bucharest: Editura Academiei, 1965), 60.
} 
extends across approximately three quarters of a century. It contains two major sections - from the first chapter to chapter 41, the plot centres around the protagonist, Genji, the son of the Emperor and of one of the consorts, and the second section, from chapter 42 to 54, contains the story of Genji's descendants. In spite of the apparent lack of interest for the chronology, the novel follows a subtle logic of events from Genji's life, a sinuous one, with ups and downs until the end, when he reaches full maturity and is once again elevated to the highest rank as jun daijō tennō (honorary retired emperor). This fickle rhythm of fate is connected to the already recurring theme in the literature of that time, in which the imperial offspring face the hardships of destiny and the malice of men, but, in the end, they find their place within the world to which they belong. Genji's existence and the series of the most important events of his life, from birth to death, provide an artistic unity to a story that does not, however, concern itself primarily with chronology. But Murasaki Shikibu does not ignore the significance and value of temporality, quite the contrary, she offers its flow an epic dimension, but the chronology is not as important, for the author, as are her characters, who seem to live outside historical time, even if their existence is directly connected to time through a network of unseen lines. Another interesting aspect is the fact that the story is told in the third person, but the use of the inner monologue, and the author's emotional involvement through subtle metatextual insertions allow for the rendition of the narration in the first person as well.

Considering the age of this text, as well as the scarcity of historical references about the period in which it was written, the question regarding the extent to which Genji monogatari speaks of the world within which it came into being is not only legitimate, but even natural, if we were to also ask to what extent such a text addresses today's generation. This issue leads to a discussion about the very nature of the mimesis in Genji monogatari. The nature of the relation between the text and reality and between the text and the world is essential in this novel and, beyond the western theories that analysed this type of connection, in Genji monogatari the relation between the world, namely the Heian Court that is represented here, and the text as literature does not reveal itself in the narration from the very beginning, but gradually, as the story unfolds. Thus, the text begins in an undefined time, suggesting a time of the story, but, gradually, as the plot advances, an idea about the nature of fiction is outlined, which Murasaki Shikibu also discusses in chapter 25, entitled Fireflies (Hotaru).

In this chapter, through the voice of prince Genji, Murasaki Shikibu states her own opinion about discourse and, from an ethical viewpoint, she makes a distinction between the historical discourse, the literary discourse and the religious discourse: "We are not told of things that happened to specific people exactly as they happened; but the beginning is when there are good things and bad things, things that happen in this life which one never tires of seeing and hearing about, 
things which one cannot bear not to tell of and must pass on for all generations. (...) Even in the writ which the Buddha drew from his noble heart are parables, devices for pointing obliquely at the truth." About the historical discourse, encountered in the chronicles Kojiki and Nihongi, prince Genji states that it depicts events of old, but it cannot cover everything. About the literary discourse, he states that it particularly depicts the ups and downs of people's lives in order to offer lessons to the future generations, but the represented truth is imaginary. Even the religious discourse uses stratagems in order to help people understand Buddha's teachings but, in order to achieve enlightenment, the discourse may stray from the truth, servicing the religious intention. A very interesting aspect is that Murasaki Shikibu does not actually define discourse by what it is, but by its purpose and intentions. Thus, the historical discourse plays the role of preserving and disseminating the truth of the events of old, the literary discourse also contains an ethical, formative intention and the religious discourse proposes the use of the parable in the transmission of Buddha's teachings.

If the initial nature of the relation between the world and the text, in the sense of the mimesis, can determine us to admit that the writer merely transposes into words the reality of the world in which she lives, as the text is constructed, we may realise that Murasaki Shikibu sensed that the purpose of the mimesis is not to create an illusion of reality but, through intertextuality, in the sense defined by Julia Kristeva, ${ }^{4}$ an illusion of the discourse about reality, which, even today, confers this novel its value and its immense expressive force. Thus, in the chapter Fireflies (Hotaru), prince Genji asks his protégé Tamakazura what she is reading, which leads to a dialogue about literature and which allows Murasaki Shikibu to thus raise the issue of the nature of literature, through the conversation between the two protagonists. In spite of the apparent simplicity of the lines, the prince begins by criticising the monogatari genre, making a distinction between monogatari, a genre addressed especially to women, who most often also copied these stories, and the historical writings, like the chronicles Kojiki and Nihongi, a serious genre reserved for men. If the monogatari type stories, as Genji suggests, tend to obliterate, through their fictitious nature, the real world, giving a naïve reader the false impression that this world is similar to the made-up one, the events described in the chronicles, although true, cannot comprise reality in its entirety, which is why they are incomplete: "The Chronicles of Japan and the rest are a mere fragment of the whole truth. It is your romance that fill in the details. ${ }^{5 "}$ However, upon returning to his initial opinion, which seemed to favour the historical writing as opposed to

\footnotetext{
${ }^{3}$ Murasaki Shikibu, The Tale of Genji, transl. and ed. by Edward G. Seidensticker (New York: Alfred A. Knopf, 1992), 459-460.

4 Julia Kristeva, Sèméiôtikè. Recherches pour une sémanalyse (Paris: Seuil, 1969), 146.

${ }^{5}$ Shikibu, 459.
} 
monogatari, Genji takes a more nuanced stance, admitting that the monogatari genre also has its own importance, especially if the stories are painted well. Nonetheless, the prince confesses that, as far as he is concerned, he does not consider it appropriate for certain stories or monogatari to be read to his daughter, because they would merely influence her character and they would create the illusion that the reality from within the texts is true. The author offers no examples of such books, but the dialogue with Tamakazura and especially with his wife, Murasaki, shows which books would not be recommended as reading materials for the little girl. They particularly refer to the love stories: "You must not read love stories to her. I doubt that clandestine affairs arouse her unduly, but we would not want her to think them commonplace. ${ }^{6 \prime}$ Such a line, spoken by someone who placed love and desire above all else in life is rather curious. In one's personal development and in reaching the ideal of a miyabi (雅) nobleman, the preoccupation with beauty and truth cannot be fulfilled by ignoring the importance of feelings and emotions. Nevertheless, seeing Genji only as a parent, as the father of a girl whom he wishes to raise as a future empress, his line is perfectly understandable. As a father preoccupied with the future of a girl whose marriage he himself will arrange, he realises that the love stories present in the monogatari are deceitful in relation with the reality and the obligations of social life, which exclude the romanticism of true love. However, this type of attitude somewhat contradicts his own views on life, which, once again, shows the complexity of the prince's character. By invoking the Buddhist writings and the morals of the religious texts, Genji realises that the nature of literature, in general, and of fiction, in particular, actually surpasses the contradiction true/false or real/fictional, by sensing the existence, beyond the author's intention, of a superior purpose that often eludes people and this purpose is the search for beauty and goodness, not in a moral sense, but in that of an aesthetic with ethical value or an ethic imprinted in the aesthetic. Makoto Ueda sees a combination between ethic and aesthetic ${ }^{7}$ and, as such, for the purpose of seeking the absolute good, Murasaki Shikibu activates the pathos, a subtle aesthetic concept which shapes the text and offers a poetic value to the whole.

Undoubtedly, Murasaki Shikibu questioned the nature of fiction after observing the interest attracted by literature at that time. The dialogue between Genji and young Tamakazura shows that the writer was aware of the role and influence literature had on the readers and realised, beyond all doubt, that there is a subtle distinction between the literature that speaks of the world and the literature that speaks of literature. The historical writings, as well as the writings that refer to the world explicitly, represent a category of texts that are different from the writings

\footnotetext{
${ }^{6}$ lbid., 461.

7 Makoto Ueda, Literary and Art Theories in Japan (Cleveland, Ohio: The Press of Western Reserve University, 1967), 36.
} 
which, in the author's opinion, resort not necessarily to describing the world, but to representing it through an in-depth knowledge of the literary tradition, while also relying on the author's talent to construct an intrigue or a story. Thus, in Murasaki Shikibu's case, the intrigue is the one that saves the narration from fragmentarism, an intrigue which, although linear, since the succession of events is not always natural, actually implies an internal connection that is not necessarily chronological, but rather psycho-logical. In Genji monogatari, orality does not transpire on a stylistic level, which explains why its importance is overlooked in the economy of the novel, but rather on the level of the mimesis, namely in the representation of the plot and the coherent chain of events. As opposed to her previous novels, Murasaki Shikibu, beginning from the models of the oral literature, constructed an intelligible, universal and plausible intrigue, in the sense defined by Ricoeur, namely by demarcating the intelligible from the accidental, the universal from the singular, the necessary or the plausible from the episodic ${ }^{8}$.

In the novel, the narrative time displayed in succession, without always overlapping the historical time of the events, is the most important aspect of narration, creating the referential illusion or, in Barthes' terms, the "effect of reality. ${ }^{\prime \prime}$ The supernatural elements, which are few and not too exaggerated, do not impede the plot and do not deviate the nature of the story towards the area of the fairy tale or that of the fantasy writings; quite the contrary, they merely emphasise the rather realist style of the writing. Such elements are actually related to the epoch's approach to the miraculous or the supernatural, which is why it is only natural that the characters of the novel manifest beliefs and superstitions that can be found in the thought and sensibility of the times to which they belong. It is, however, less clear whether the author herself shares her characters' beliefs since, while playing the role of the objective author who does not intervene with additional explanations, Murasaki Shikibu offers the reader the freedom of choice. In this sense, an illustrative episode is that of the death of Genji's wife, Aoi, whose premature departure is suggested to have been caused by the evil spirit of Lady Rokujō. The presence of superstitions and beliefs does not, however, smother the storyline - on the contrary, it provides even more authenticity and relevance.

However, in order to better understand the relation between literature and history, we must follow the relation between literature and society. To say that literature mirrors life or represents it is simultaneously too little and too much, as well as quite ambiguous.

An essential role in the economy of the novel Genji monogatari is played by the ceremonies and the court rituals. The entire court takes part in the ceremonies

\footnotetext{
8 Paul Ricoeur, Temps et récit. L'Intrigue et le récit historique (Paris: Seuil, 1983), 60.

9 Roland Barthes, "L'effet du reel," in Roland Barthes, Leo Bersani, Philippe Hamon, Michael Riffaterre, lan Watt, Littérature et Réalité (Paris: Seuil, 1982).
} 
occasioned by the moments that mark the succession of the seasons. One of the court events in which the protagonist is young Genji was The Festival of Red Leaves (Momiji-no-ga), an occasion upon which the price danced the "Waves of the Blue Ocean" ritual dance, inciting everyone's admiration. Even his stepmother, princess Kokiden, acknowledged Genji's merits: "Surely the gods above are struck dumb with admiration. ${ }^{10 "}$ In order not to attract the malice of the evil spirits, who would have been envious of the prince's beauty, the Emperor, concerned with his well-being, asked for prayers for favour, which stirred the stepmother's discontent. The image of Genji's perfection is completed by his artistic talents, unveiled in the following chapter, upon the occasion of The Festival of the Cherry Blossoms (Hana no en). Since, at that time, the Emperor was interested in Chinese poetry, the fashion of the Chinese poetic style was also imposed at the Japanese Court. Thus, during The Festival of the Cherry Blossoms, there was also a poetry contest in which each participant composed (based on a given theme) poetry in a Chinese manner, which they then recited in front of everyone. Genji's compositions incited everyone's admiration and even the professional poets were impressed by the quality of the prince's verses.

Such ceremonies, which were traditional for the life of the court or for the celebration of certain important events, are not singular in the economy of the novel, since they are completed by sacred or religious rituals. One such ritual is that of the consecration of the priestess from Kamo. Fate had decided that the priestess of the temple in Kamo be Sannomiya, the third daughter of the former emperor from his marriage to Kokiden. Several days before the investiture, the ceremony for the purification of the Kamo River took place. Upon this occasion, the Emperor himself had chosen the garments and the colours of the clothes of the young nobles who were meant to await the princess in a preestablished location. Prince Gneji was also chosen to be part of the cortege. The exceptional talent with which Murasaki Shikibu describes not only the well-known moments of the ritual, but especially the stuffy crowd gathered to see the ceremony, out of which she chooses certain onlookers (Rokujō, Prince Momozono, Princess Asagao) who saw the event from different angles, confers the scene dynamism and additional energy. Another remarkable scene is that in which there is an incident between the coachmen and the attendants of the two women, wife Aoi and Lady Rokujō, who were at that time disputing Genji's heart. This incident also plays the significant role of anticipating the events that would follow: Aoi's malady, her spirit's possession by the spirit of Lady Rokujō and the death of Genji's wife.

Another essential aspect of the novel is represented by the description of court etiquette. However, the description of court protocol, of the way in which the courtiers dressed, in accordance with their ranks or the court customs, does not

10 Shikibu, 140. 
receive a particularly special focus. More important than their description is the way in which the characters, in certain circumstances, interpret the others' behaviours, the colours or tailoring of their garments or certain gestures that, especially in unusual moments, gain multiple meanings. It would appear that the law that governs the Heian world is not desire or the fulfilment of love, but the sublimation of desire and of sensuality by aestheticizing the erotic impulses; thus, the true law imposed in the Heian Court is the inevitable aspiration of the aesthetic and poetic ideal of love. This aesthetic and poetic ideal represents a true reference, a standard that establishes the border between the lovers' needs and impulses and the ideal which everyone aspires to embody. And yet, if in the world of the European medieval chivalric novels there is a spiritual (sacralised) reference by which the enamoured knight sublimated his desire, thus managing to consecrate himself to the love ideal accepted by the codes of chivalric love, in the Heian world, the place of the spiritualised reference is occupied not by an absolute image, but by a series of poetic representations which, depending on the individual aspirations, impose or create a new reference. By embodying the image of an ideal, Genji could pass as an implausible character. However, despite the perfection of his nature (he was the perfect courtier - a true miyabi) and despite all of the gifts he had been endowed with, he kindles not only the admiration of those around him, but also much envy and hatred. Moreover, his temper's inclination towards sadness and melancholy helps him discover, even in the midst of the most intense joy or artistic feeling, the imperceptible signs of the ephemeral nature of things. Thus, by showing the hero's inability to respond to the envy and hatred of those around, and by providing the hero with the painful consciousness of the evanescence of the world and of things, Murasaki Shikibu managed to salvage Genji's image from an implausible or excessive idealisation. Even Genji's erotic experiences are far from perfect or ideal; quite the contrary, they have a certain fatalism that confers them a melancholic nuance. When the distance between the impulses or feelings and the ideal deepens into a gap, the void thus created gives way to a conflict that is often dramatic and, inevitably, has an ending that somewhat casts a shadow upon the entire world.

Thus, as opposed to history, literature operates with models, motifs, seeking typicality and, as such, universality, since the human feelings, experiences and thoughts can, in analogous circumstances, be similar or identical, because people react to extreme situations in the same way.

If the historical events' ambition is to comprise a totality, and the historian tends to describe the entire mechanism and to reconstruct all of the component elements through a narration that is made up of an accumulation of information and data certified by documents, literature can fragment itself, it can sever the levels of presentation of the epic events and it can be sequential. Modern literature in particular operates with this kind of ruptures of levels and changes in perspective. From this viewpoint, the epic narration functions in a logic of recurrence and it does 
not hesitate to use and reinterpret the literary topoi, to revalue the literary tradition by giving the old literary motifs new shapes and contents.

As a representation of the world that birthed it, beginning with the $17^{\text {th }}$ century, together with the rediscovery of the literature of the Heian period and its integration in the public circuit, Genji monogatari also received a function that shaped the Japanese culture, continually influencing both literature and the rest of the arts, to the present day. By activating the dimension of temporality, and due to its representativity of the world, the novel Genji monogatari surpassed the folkloric character of the stories of old (mukashi monogatari) and, in time, by proving its vivacity and renewal force, it will become the expression of a new literary genre.

Translated from Romanian by Anca Chiorean 